\title{
オキアミ類の含窒素化合物に関する研究
}

\author{
須山三干三・中島喜久一・野中順三九 \\ (1965 年 2 月 6 日受理)
}

\section{STUDIES ON THE PROTEIN AND NON-PROTEIN NITROGENOUS CONSTITUENTS OF EUPHAUSIA}

\author{
Michizo Suyama, Kikuichi Nakajima and Junsaku Nonaka*
}

Euphausia, a kind of mysis, is known as a feed stuff of aquatic animal and cetacean; thenutritive constituents of the Euphausia are being watched with interest from the biochemical as well as technological points of view. In the present experiments, the protein and non-protein nitrogenous constituents of the Euphausia, E. pacifica, E. superba and E. vallentini. have been analysed by the automatic amino acid analyser or by the individual chemical methods.

The chemical compositions of fresh samples are given in Table 1, and the amounts of crude protein were around $17 \%$. The pattern of amino acids in hydrolysates of protein given in the Table 2 was similar to that of muscle protein of common crustacean reported by theother authors, but somewhat higher content of tryptophan in the present samples are of in. terest from the nutritional viewpoint.

The amount of extractive nitrogen of E. pacifica (whole) was higher than that of $E$. superba (muscle), and the concentrations of peptide-composing amino acids, free amino acids and their related compounds of these two are tabulated in Table 3. Relatively large amounts of alanine, glycine, proline, arginine, taurine, trimethylamine oxide and betaine were found, and the calculations of nitrogen summarized in the table show that 94 and $96 \%$ of extractive nitrogen are respectively accounted for.

オキアミ類は外洋にひるく分布するアミの一種で, 水産動物の䬺料として知られている。ことに南氷洋に

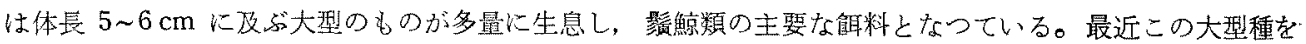

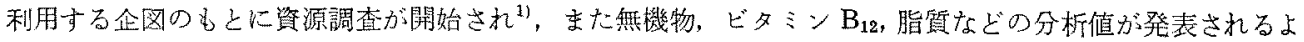
らになつでる゙，よらやくオキアミ類に関する知見がるえつつある。

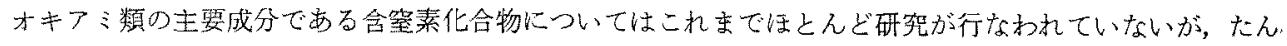
に利用の見地からばかりでなく生化学的見地からいつても，含窒素化合物の研究には興味深いものがある。

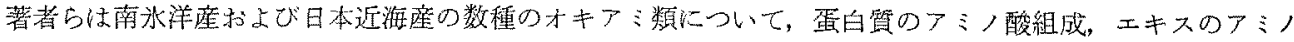
酸扎よび関軖化合物の組成などを分析したので,これを報告する。

\section{実 験 方 法}

\section{試料}

研究に使用したオキアミ類は次の3 種5 检体である。（1）および（5）は絧によつて漁獲したるのであり，

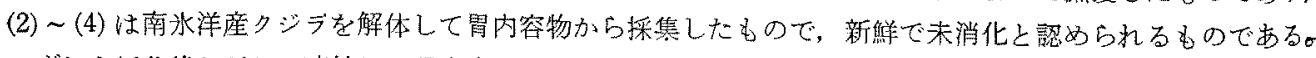
いずれも採篹媵ただちに涷結し，研究室に搬入して分析に用いた。

(1) Euphausia pacifica：体㷌 $1.5 \sim 2.0 \mathrm{~cm}$, 三陸沖珄

\footnotetext{
* 東京水䃌大学 (Tokyo Univ. of Fisheries; Shiba, Minatoku, Tokyo)
} 
(2) Euphausia vallentini：体長 $2.0 \sim 2.5 \mathrm{~cm}$, 南水洋産

(3) Euphausia superba (A): 体長 $3.0 \sim 4.0 \mathrm{~cm}$, 南水洋産

(4) 同上 (B): 体長 $5.0 \sim 6.0 \mathrm{~cm}$, 南水洋産

(5) 同 (C): 体長 $4.0 \sim 5.0 \mathrm{~cm}$, 南水洋産

\section{肉蛋白の調製}

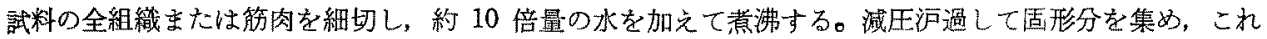

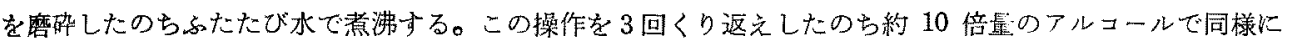
処理し，エーテルでよく脱脂してから颙燥する。完全に60メッシュのふるいをと和るまで乳鉢で粉砕して 肉蛋白試料とし,アミノ酸組成の测定に用いた。

\section{エキスの調製}

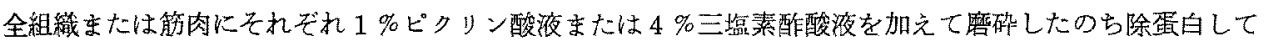
エキス抽出液とした。ピクリン酸液で抽出したものは，イオン交換樹脂 Dowex 2-X8 (Cl 型) 周をと播して ピクリン酸を除いたのb主として游離アミノ酸の定量に用い，三塩素酢酸液で抽出したものは，閣連化合物 の定量に用いたほか、エーデルで酸を除いてからぺプチド掅成アミノ酸の定量に用いた。

\section{蛋白質およびペプチトの加水分解}

調製した肉蛋白拉よびエキスを $6 \mathrm{~N}$ 塩酸とともに封管し，110て

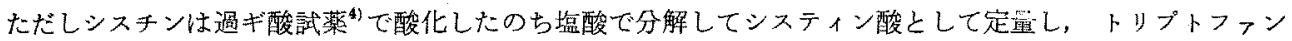
は水酸化ベリウム分解らしたるのについて定粟した。

\section{アミノ酸および関連化合物の定量}

アミノ酸およびその他のニンヒドリン陽性物質の定量はSPACKMAN 5 ${ }^{6}$ の方法に基づく自動分析装（日

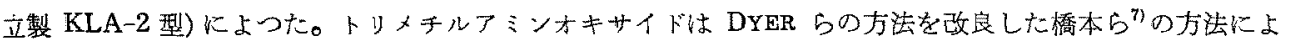

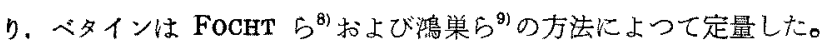

\section{結果および考察}

\section{一般分析}

二三の試料について一般分析を行なつた結果を示坻ば Table 1 のとおりである。田ロら ${ }^{10}$ は採集直後の E. superba を試料しして水分の測定を行ない，筋肉については $79.2 \%$ と $79.8 \%$ の 2 例を報告している が，Table 1 の結果とよく一致している。したがつてすくなくもこの究研に用いた E. superbaは，凍結 貯藏中の乾燥や吸水がほとんどなかつたものと考えることができる。

Table 1. The chemical composition of Euphausia. (\%)

\begin{tabular}{l|c|c|c}
\hline \hline & $\begin{array}{c}\text { E. pacifica } \\
\text { Whole }\end{array}$ & $\begin{array}{c}\text { E. superba (A) } \\
\text { Muscle }\end{array}$ & $\begin{array}{c}\text { E. superba }(\mathrm{C}) \\
\text { Muscle }\end{array}$ \\
\hline Moisture & 78.62 & 79.95 & 79.69 \\
Crude protein & 16.65 & 17.75 & 17.41 \\
Lipids & 1.48 & 1.31 & 1.64 \\
Ash & 3.11 & 1.43 & 1.45 \\
\hline
\end{tabular}

\section{蛋白質のアミ/酸組成}

全組織または筋肉について蛋白質のアミノ酸組成を測定した結果は Table 2 に示すとおりである。これ に上れば蛋白質のアミ，酸組成は相互に近似し，またクルマェビやシバェビなどの一般の中散類についての

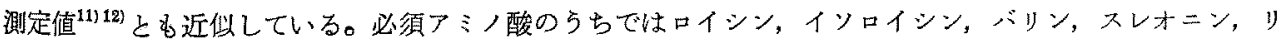
ジン、メチオニンなどに富んでいるが，重肉蛋白に批る分布と大差ない。トリプトファン荨量は E. val-

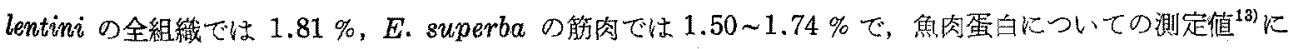


Table 2. The amino acid compositions of the proteins of Euphausia. (g. of amino acid in hydrolysate from $100 \mathrm{~g}$. of protein.)

\begin{tabular}{|c|c|c|c|c|c|c|}
\hline Amino acid & $\begin{array}{c}E \\
\text { pacifica } \\
\text { Whole }\end{array}$ & $\begin{array}{l}\text { E. } \\
\text { vallentini } \\
\text { Whole }\end{array}$ & $\begin{array}{c}E . \\
\text { superba (A) } \\
\text { Whole }\end{array}$ & $\begin{array}{c}E \\
\text { superba (A) } \\
\text { Muscle }\end{array}$ & $\begin{array}{c}E . \\
\text { superba (B) } \\
\text { Muscle }\end{array}$ & $\begin{array}{c}\text { E. } \\
\text { 8uperba (C) } \\
\text { Muscle }\end{array}$ \\
\hline Alanine & 5.61 & 5.88 & 5.46 & 5.83 & 6.06 & 6.01 \\
\hline Glycine & 5.35 & 4.87 & 4.67 & 4.58 & 4.49 & 4.62 \\
\hline Valine & 5.19 & 5.35 & 5.90 & 5.38 & 5.44 & 4.72 \\
\hline Leucine & 7.83 & 8.35 & 7.77 & 8.47 & 8.72 & 8.28 \\
\hline Isoleucine & 5.16 & 5.28 & 5.10 & 5.50 & 5.53 & 5.25 \\
\hline Proline & 3.47 & 3.33 & 4.21 & 3.36 & 3.36 & 3.35 \\
\hline Phenylalanine & 6.50 & 6.64 & 6.47 & 6.35 & 5.68 & 6.32 \\
\hline Tyrosine & 4.15 & 4.12 & 4.06 & 4.29 & 3.99 & 4.51 \\
\hline Tryptophan & 1.57 & 1.74 & 1.50 & 1.60 & 1.68 & 1.70 \\
\hline Serine* & 4.82 & 4.71 & 4.95 & 4.90 & 4.73 & 3.91 \\
\hline Threonine & 4.83 & 4.80 & 4.70 & 4.65 & 4.74 & 4.20 \\
\hline Cystine & 1.35 & 1.22 & 1.45 & 1.14 & 1.28 & 1.35 \\
\hline Methionine & 3.25 & 3.18 & 3.03 & 3.53 & 3.29 & 3.44 \\
\hline Arginine & 5.95 & 5.92 & 6.22 & 6.83 & 7.16 & 7.08 \\
\hline Histidine & 2.22 & 2.11 & 2.30 & 2.16 & 2.06 & 2.40 \\
\hline Lysine & 7.84 & 8.55 & 8.58 & 9.50 & 8.94 & 10.2 \\
\hline Aspartic acid & 13.7 & 12.5 & 12.2 & 12.0 & 12.3 & 12.5 \\
\hline Glutamic acid & 14.7 & 14.6 & 14.6 & 15.0 & 15.7 & 15.3 \\
\hline Giucosamine & 2.04 & 2.44 & 3.45 & & & \\
\hline Amide $\mathrm{N}$ & 1.40 & 1.34 & 1.37 & 1.23 & 1.19 & 1.26 \\
\hline Total amino acid & 105.53 & 105.59 & 106.62 & 105.07 & 105.15 & 105.14 \\
\hline $\mathrm{N}$ recovered $(\%)$ & 96.81 & 96.67 & 97.05 & 97.41 & 97.44 & 98.55 \\
\hline
\end{tabular}

* Values corrected by $10 \%$ to compensate for destruction during acid hydrolysis.

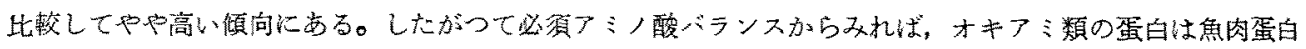
よりも㫍れていることが推祭でるる。

\section{エキスの會素化合物}

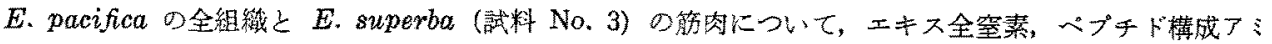

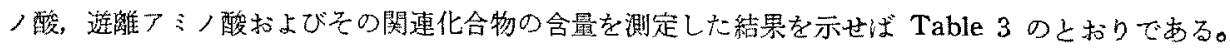

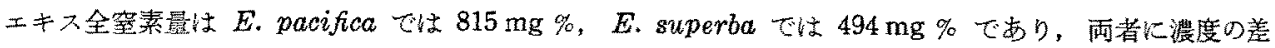

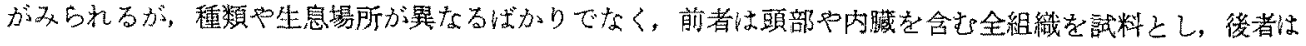

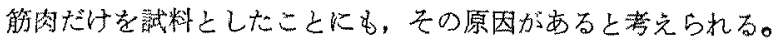

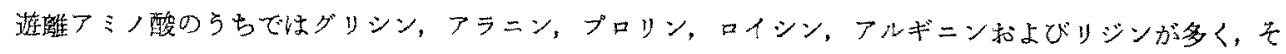

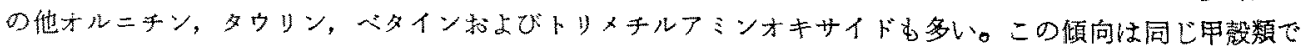
あるクルマエビの場合 ${ }^{4)}$ と一応は類贷しているが，しかしクルマエビのべタイン量が $640 \mathrm{mg} \%$ に及゙こ

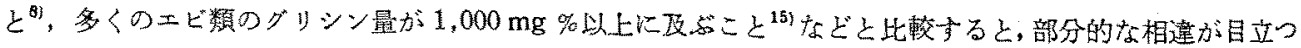

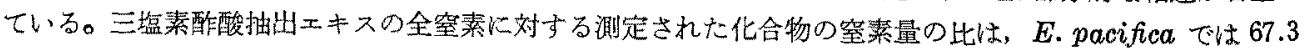
\%, E. superba では $70.3 \%$ でつた。

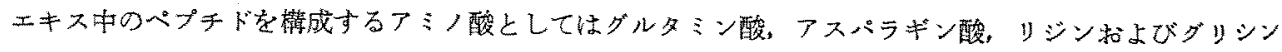
が多く、ことにグルタミン酸の占める割合が大きい。エキスに含まれるべプチドの量は除䖝白阂の種類によ

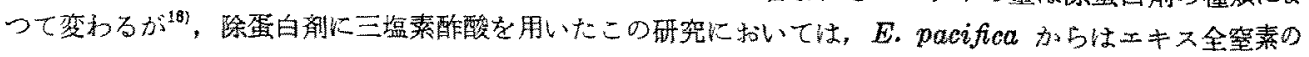


Table 3. The nitrogenous constituents of the extractives of Euphausia. ( $\mathrm{mg}$. of constituent in extractives from $100 \mathrm{~g}$. of sample.)

\begin{tabular}{|c|c|c|c|c|}
\hline \multirow[b]{2}{*}{ Compound } & \multicolumn{2}{|c|}{ E. pacifica, Whole } & \multicolumn{2}{|c|}{ E. superba (A), Muscle } \\
\hline & $\begin{array}{l}\text { Free amino acid } \\
\text { and related } \\
\text { compound }\end{array}$ & $\begin{array}{l}\text { Peptide- } \\
\text { composing } \\
\text { amino acid* }\end{array}$ & $\begin{array}{c}\text { Free amino acid } \\
\text { and related } \\
\text { compound }\end{array}$ & $\begin{array}{c}\text { Peptide- } \\
\text { composing } \\
\text { amino acid* }\end{array}$ \\
\hline Alanine & 214 & 44.0 & 106 & 35.0 \\
\hline Glycine & 374 & 135 & 116 & 79.0 \\
\hline Valine & 92.1 & 28.9 & 62.7 & 22.7 \\
\hline Leucine & 103 & 35.0 & 85.6 & 19.4 \\
\hline Isoleucine & 69.0 & 28.1 & 48.4 & 12.5 \\
\hline Proline & 221 & 41.0 & 217 & 33.0 \\
\hline Phenylalanine & 55.8 & 7.6 & 53.3 & 13.0 \\
\hline Tyrosine & 16.8 & 6.7 & 47.6 & 8.6 \\
\hline Serine & 52.5 & 48.5 & 42.7 & 29.1 \\
\hline Threonine & 91.0 & 30.0 & 53.6 & 11.7 \\
\hline Cystine & 0 & 12.7 & 0 & 9.8 \\
\hline Methionine & 48.8 & 19.5 & 33.9 & 21.7 \\
\hline Arginine & 131 & 25.0 & 266 & 19.0 \\
\hline Histidine & 28.7 & 20.1 & 16.5 & 11.2 \\
\hline Lysine & 320 & 166 & 145 & 72.0 \\
\hline Aspartic acid & 46.6 & 154 & 52.0 & 75.0 \\
\hline Glutamic acid & 28.0 & 333 & 35.1 & 172 \\
\hline Glutamine & 39.6 & & 22.8 & \\
\hline Ornithine & 151 & & 42.3 & \\
\hline Taurine & 382 & & 206 & \\
\hline Betaine & 269 & & 106 & \\
\hline$\beta$-alanine & 13.0 & & 34.6 & \\
\hline Trimethylamine oxide & 417 & & 212 & \\
\hline Ammonia $\mathrm{N}$ & 52.2 & 61.5 & 18.1 & 40.5 \\
\hline Total $\mathrm{N}$ calculated & 548.7 & 216.6 & 347.1 & 127.8 \\
\hline Total $\mathrm{N}$ determined & \multicolumn{2}{|c|}{815} & \multicolumn{2}{|c|}{494} \\
\hline $\mathrm{N}$ recovered $(\%)$ & \multicolumn{2}{|c|}{93.9} & \multicolumn{2}{|c|}{96.2} \\
\hline
\end{tabular}

* The amounts are calculated from the difference between the values before and after hydrolysis.

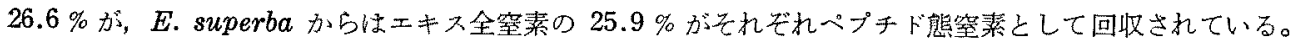

遊離アミノ酸扰よびその他のニンヒドリン陽性物質のクロマトグラフィーを行なつた結果，エキス中にほ

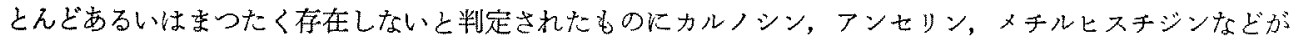

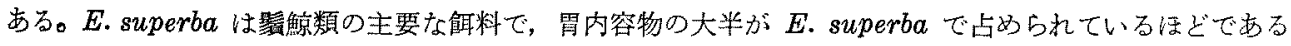

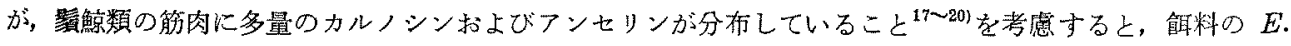
superba がカルノシンやアンセリンに欠けているのは與味深い。

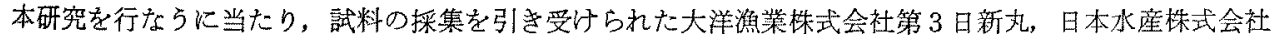

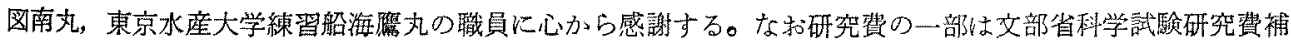
助金によつて支払われたことを付記する。 


\section{文献}

1) 城戸卓夫・井上実：東京水産大学特別研究報告, 7 (2), 71 (1964).

村野正昭: 同上, 7 (2), 91 (1964).

2) 平野敏行 - 菊池武昭 - 烊田雄之助: 本誌, 30, 267 (1964),

3) 野中順三九 -小泉千秋: 同上, 30, 630 (1964).

4) E. Schram, S. Moore and E. J. Bigwood: Biochem. J., 57, 33 (1954).

5) R. D. Greene and A. Black: J. Biol. Chem., 155, 1 (1944).

6) D. H. Spackman, W. H. Stein and S. Moore: Anal. Chem., 30, 1190 (1958).

7) 橋本芳郎・成市友利: 本誌，23，269(1957).

8) R. L. Focht and F.H, Schmmt: Agr, Food Chem., 4, 547 (1956).

9) S. KōNosu and E. KAsAI: This Journal, 27, 194 (1961).

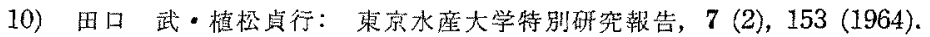

11) 鸿策章二・香取進一・秋山明子・森 高次郎：本誌，24，300(1958).

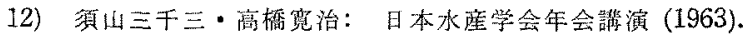

13) S. KÖNOSU and F. MAtsuURA: This Journal, 26, 1040 (1960).

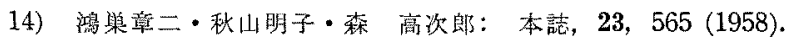

15) 清水 亘・藤田殖夫: 同上, 20,720 (1954).

16)須山三千三：“水座物のエキス”，日本本産学全秋季大会シンポジムテキスト(1957).

17) K. Horisaka and A. Musashi: J. Biochem., 53, 271 (1913).

18) T. NAKaI, N. TsUJigado and S. AkIYA: ibid., 54, 541 (1963).

19）日下部寛男 -小鼠喜久.片山敏子：理研報告, 38, 107 (1962).

20) A. LuKTon and H.S. OlcotT: Food Res., 23, 611 (1958). 